\title{
PROSTATIC HYPERPLASIA AND SOCIAL CLASS
}

\author{
BY
}

\author{
I. M. RICHARDSON
}

From the Department of Social Medicine, University of Aberdeen

It has been known for many years that death rates from hyperplasia of the prostate are higher in the upper social classes (Registrar General for England and Wales, 1958). Although Walker (1922), in his Hunterian lecture, stated that prostatic enlargement "is found more frequently among the well-to-do than the hospital class", little attention seems to have been given to this association between prostate disease and social class. If the association is real it would suggest that an environmental factor may be concerned in the aetiology and thus point towards preventive action.

This paper examines further the relationship between prostate disease and social class using both mortality and morbidity data.

\section{Prostate Mortality in Scotland}

From tabulations specially provided by the Registrar General for Scotland, age-specific death rates from prostatic hyperplasia were calculated by social class (Fig. 1).

The social class gradient-highest in Classes I and II (professional and managerial occupations) and lowest in Classes IV and V (least skilled occupations)-is present in each age group, but the difference between the upper and middle classes is greater than between the middle and lowest classes. Scottish mortality data therefore confirm the English findings.

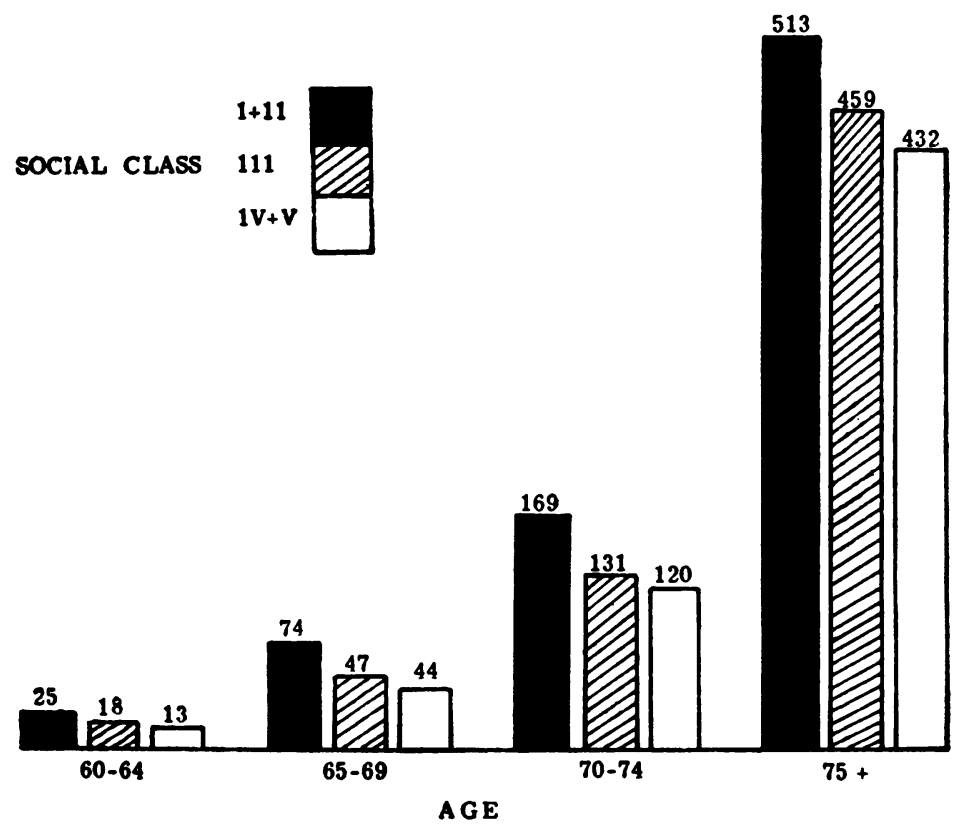

FIG. 1.-Death rate per 100,000 population per annum (Scotland, 1951-55), 


\section{Hospital Admission Rates}

To see whether morbidity rates showed a similar social class gradient, a census was carried out of all patients who were admitted with benign prostatic disease to hospitals and nursing homes in the northeast region of Scotland (City of Aberdeen, Counties of Aberdeenshire, Kincardineshire, Banff and Moray). This census covered the years 1961 and 1962 and was based on three sources of information.

(1) The central records department in Aberdeen Royal Infirmary provided the case notes of all inpatients whose diagnosis had been assigned to No. 610 (hyperplasia of prostate) or No. 786.1 (retention of urine) of the International Classification of Diseases (ICD). These hospital records were examined and where the diagnosis of prostatic hypertrophy was confirmed particulars were transferred to cards.

(2) A source which both checked and complemented the first was the Hospital In-patient Inquiry being conducted by the Scottish Home and Health Department. Special regional tabulations provided information about all hospital patients with ICD numbers 610 and 786.1, and using these data it was possible to obtain case notes from peripheral hospitals for scrutiny and abstraction.

(3) The consultant surgeons in the area kindly provided lists of patients with prostate disease who had been treated privately, and the nursing home admission registers were used to check that all such cases had been included.

As it was realized that some patients living at the edge of the north-east hospital region might be treated in hospitals of the adjoining regions, inquiry was made through the records officers of these outlying hospitals. This investigation brought to light four additional patients.

To calculate hospital admission rates it was necessary to estimate the north-east population by age and social class. The relevant 1961 Census figures were not available, and the 1951 Census data were used in the following way:

The proportional social class distribution of all males in the north-east area was applied to the number of males in each age group over age 50 to give population denominators by age and social class. To allow for differences between social class distributions in those under and over age 70, for ageing of the population between 1951 and 1961, and for changes in social class during that period, corrections were made using various national statistics. As none of these crude modifications altered the trends to be reported it was decided to omit them and to use simply the populations by age and social class estimated direct from the 1951 Census data.

The fact remains however that social class distributions in very old men are of somewhat doubtful validity, and this must be borne in mind when interpreting the findings.

The annual hospital admission rates (average of the two years) calculated from these estimates are shown in Fig. 2 (opposite).

Like the mortality data, these hospital morbidity rates show an excess in the upper social classes, but there is a tendency to reversal of the relationship between the middle and lower social groups. There was in each social class a slightly higher admission rate in the city compared with the rest of the region. When the data were combined to give two age groups the excess of admissions in Social Classes I and II was highly significant (i.e. at the 1 per cent. level) in men both below and above age 70 .

It therefore seems clear that, in this region, the upper social classes are more often admitted to hospital with prostatic hyperplasia. This higher admission rate could be due either to a genuinely higher prevalence of prostate disease in men from the better-off social groups, or to their greater willingness to seek treatment, or to a combination of these two factors.

\section{Prevalence of Prostatic Hyperplasia}

Two pieces of evidence were used to explore the biological explanation of these mortality and hospital admission findings:

(1) The prevalence of prostatic symptoms and prostatectomy in a population sample was examined;

(2) A series of prostate glands removed at autopsy was weighed.

During a socio-medical survey of older men in north-east Scotland carried out in 1958-60 (Richardson, 1964), questions were asked about nocturnal frequency of micturition. The findings are shown in Table I.

TABLE I

NOCTURIA IN 232 MEN, AGED 60 AND OVER, N.E. SCOTLAND, 1958-60, BY SOCIAL CLASS

\begin{tabular}{|c|c|c|c|c|c|}
\hline \multirow{2}{*}{$\begin{array}{l}\text { Social } \\
\text { Class }\end{array}$} & \multicolumn{3}{|c|}{$\begin{array}{l}\text { Percentage with Nocturnal } \\
\text { Frequency }\end{array}$} & \multirow{2}{*}{$\begin{array}{l}\text { Percentage } \\
\text { Previous } \\
\text { Pros- } \\
\text { tatec- } \\
\text { tomy }\end{array}$} & \multirow{2}{*}{$\begin{array}{l}\text { No. of } \\
\text { Men } \\
\text { (100 } \\
\text { per } \\
\text { cent.) }\end{array}$} \\
\hline & $\begin{array}{l}\text { Never or } \\
\text { Occa- } \\
\text { sionally }\end{array}$ & $\begin{array}{l}\text { Once or } \\
\text { Twice }\end{array}$ & $\begin{array}{l}\text { Three or } \\
\text { More }\end{array}$ & & \\
\hline $\begin{array}{l}\text { I and II } \\
\text { III } \\
\text { IV and V }\end{array}$ & $\begin{array}{l}55 \\
50 \\
48\end{array}$ & $\begin{array}{l}31 \\
34 \\
35\end{array}$ & $\begin{array}{r}7 \\
14 \\
15\end{array}$ & $\begin{array}{l}7 \\
3 \\
2\end{array}$ & $\begin{array}{l}89 \\
95 \\
48\end{array}$ \\
\hline
\end{tabular}




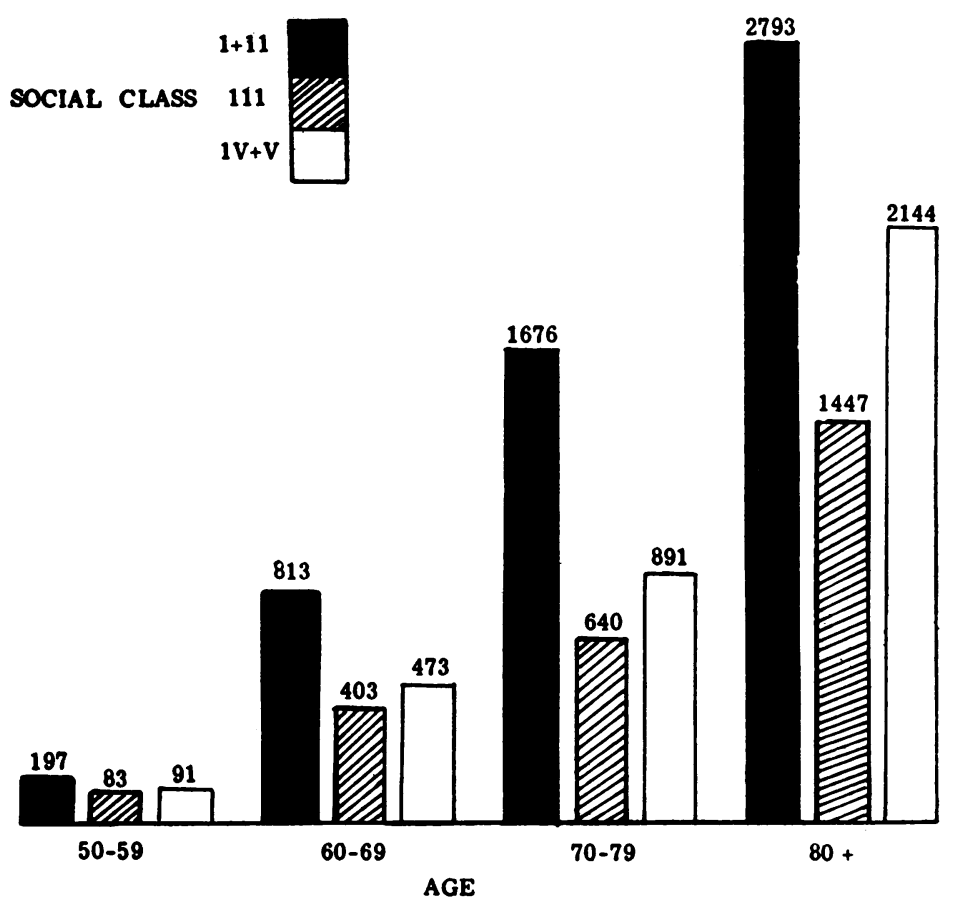

Fig. 2.-Hospital Admission rates per 100,000 population per annum (North-East Scotland. 1961-62).

Although the differences between social class prostatectomy rates are not significant, the slightly higher rate in upper class men is in line with the findings from the larger hospital admission study. If it be assumed that men who had undergone prostatectomy would, without operation, be suffering fairly severe nocturnal frequency and may therefore be combined with those who had to rise three or more times per night, then variation between social classes in respect of nocturnal frequency of micturition virtually disappears. So, if this symptom be taken as the criterion of prostate disease it may be suggested that Table I shows no real evidence of a higher true prevalence in the upper social class.

The second source of information was the postmortem weight of prostate gland. From a consecutive series of 118 men age 50 and over, who came to autopsy for non-prostatic reasons, the prostate gland was removed, weighed, and sectioned. The deceased man's social class was obtained from the death registers of the Medical Officer of Health. Table II contains the results.

Though the differences between social classes are not significant, it is interesting to note that the mean prostatic weight is distinctly greater in Classes I and II. This autopsy evidence does seem to point
TABLE II

PROSTATE WEIGHT AT AUTOPSY, BY SOCIAL CLASS

\begin{tabular}{l|c|c|c}
\hline $\begin{array}{c}\text { Social } \\
\text { Class }\end{array}$ & $\begin{array}{c}\text { No. of } \\
\text { Prostates }\end{array}$ & $\begin{array}{c}\text { Mean Weight } \\
\text { (g.) }\end{array}$ & $\begin{array}{c}\text { Standard } \\
\text { Error }\end{array}$ \\
\hline I and II & 27 & $45 \cdot 5$ & $2 \cdot 1$ \\
III & 48 & 40.7 & $2 \cdot 3$ \\
IV and V & 43 & 42.8 & $2 \cdot 8$ \\
\hline
\end{tabular}

towards the biological hypothesis of a higher real prevalence of prostatic disease in better-off men, but a larger series, using more refined methods, is needed before any firm conclusions can be drawn.

\section{RETENTION OF URINE}

The possibility remains that, though prostate disease is equally prevalent among the social classes, upper class men are more willing to seek relief from its symptoms. If acute retention of urine is a sign of delay in seeking treatment there should be a social class gradient in the proportion of patients admitted to hospital who were in retention (Table III, overleaf).

Over the age of 70 upper class men presented significantly less often with acute retention but the class differences are not striking. So if acute retention is a result of delay it seems reasonable to say that 
TABLE III

PROPORTION OF PROSTATE PATIENTS ADMITTED WITH ACUTE RETENTION TO HOSPITALS IN N.E. SCOTLAND. 1961-62, BY AGE AND SOCIAL CLASS

\begin{tabular}{|c|c|c|c|}
\hline \multirow{2}{*}{\multicolumn{2}{|c|}{$\begin{array}{l}\text { Social } \\
\text { Class }\end{array}$}} & \multicolumn{2}{|c|}{ Age } \\
\hline & & $50-69$ & 70 and Over \\
\hline $\begin{array}{l}\text { I and II } \\
\text { III .. } \\
\text { IV and V }\end{array}$ & $\begin{array}{l}. \\
\ldots \\
\ldots\end{array}$ & $\begin{array}{l}30 \\
71 \text { ( } 42 \text { per cent.) } \\
40 \\
76 \text { ( } 53 \text { per cent.) } \\
28 \text { ( } 46 \text { per cent.) }\end{array}$ & $\begin{array}{l}59 \\
101 \\
70 \\
\overline{96} \\
98 \text { per cent. }) \\
\frac{64}{91}(70 \text { per cent. }) \\
\text { cent. })\end{array}$ \\
\hline All & . & $\frac{98}{208}(47$ per cent. $)$ & $\frac{193}{288}$ (67 per cent.) \\
\hline
\end{tabular}

Table III contains some support for the alternative hypothesis that upper class men come forward earlier for hospital treatment of prostatism than do men in the lower classes. However, the probability that retention has other causes must be borne in mind.

\section{Age at Admission}

The mean age at admission of the whole group of 496 patients was $71 \cdot 5$ years; there was no significant difference between the social classes but a slight tendency to earlier admission was noted in Classes I and II compared with Classes IV and V-of the 172 upper class men 18 per cent. were over age 80 on admission whereas 24 per cent. of the 152 lower class men were over that age. Another way of looking at this point is to compare the relative increase in admission rates as age increased; if the rate at age $50-59$ in each social class is taken as 100 , then admission rates over age 80 are 1,418 in Classes I and II, 1,743 in Class III, and 2,356 in Classes IV and V. This is the trend to be expected if better-off men seek earlier treatment; prostatic symptoms tend to become worse as age increases and thus lower class men who had postponed treatment would be forced to seek admission at a later age.

\section{TREATMENT}

The type of treatment given is shown in Table IV. As only thirteen patients were treated by suprapubic cystostomy these have been combined with catheter drainage (temporary or permanent) and other non-surgical cases and this group is contrasted with the patients treated by prostatectomy (of all types).

The type of treatment was the same in each social class and each age group and, as shown in Table V, hospital case fatality rates showed no significant variation with social class (all deaths in Table $\mathrm{V}$ occurred in hospital).
TABLE IV

TYPE OF TREATMENT OF PROSTATE PATIENTS ADMITTED TO HOSPITALS IN N.E. SCOTLAND, 1961-62, BY AGE AND SOCIAL CLASS

\begin{tabular}{|c|c|c|c|c|}
\hline \multirow[b]{2}{*}{$\begin{array}{l}\text { Social } \\
\text { Class }\end{array}$} & \multirow[b]{2}{*}{$\begin{array}{l}\text { Age } \\
\text { (yrs) }\end{array}$} & \multicolumn{2}{|c|}{ Treatment (per cent.) } & \multirow{2}{*}{$\begin{array}{c}\text { Number } \\
\text { of Men } \\
(100 \\
\text { per cent. })\end{array}$} \\
\hline & & $\begin{array}{c}\text { Prostatectomy } \\
\text { and } \\
\text { Transurethral } \\
\text { Resection }\end{array}$ & Other & \\
\hline I and II & $\begin{array}{l}50-69 \\
70 \text { and Over }\end{array}$ & $\begin{array}{l}82 \\
62\end{array}$ & $\begin{array}{l}18 \\
38\end{array}$ & $\begin{array}{r}71 \\
101\end{array}$ \\
\hline III & $\begin{array}{l}50-69 \\
70 \text { and Over }\end{array}$ & $\begin{array}{l}80 \\
60\end{array}$ & $\begin{array}{l}20 \\
40\end{array}$ & $\begin{array}{l}76 \\
96\end{array}$ \\
\hline IV and $\mathrm{V}$ & $\begin{array}{l}50-69 \\
70 \text { and Over }\end{array}$ & $\begin{array}{l}87 \\
60\end{array}$ & $\begin{array}{l}13 \\
40\end{array}$ & $\begin{array}{l}61 \\
91\end{array}$ \\
\hline Total & $\ldots$ & 70 & 30 & 496 \\
\hline
\end{tabular}

TABLE V

CASE FATALITY IN PATIENTS ADMITTED WITH PROSTATE DISEASE TO N.E. HOSPITALS, 1961-62, BY AGE AND SOCIAL CLASS

\begin{tabular}{|c|c|c|c|c|}
\hline \multirow{2}{*}{$\begin{array}{c}\text { Social } \\
\text { Class }\end{array}$} & \multirow{2}{*}{$\begin{array}{c}\text { Age } \\
\text { (yrs) }\end{array}$} & \multicolumn{2}{|c|}{$\begin{array}{l}\text { Proportion of Deaths } \\
\text { (per cent.) }\end{array}$} & \multirow{2}{*}{$\begin{array}{l}\text { All } \\
\text { Treatments } \\
\text { (per cent.) }\end{array}$} \\
\hline & & $\begin{array}{l}\text { Prostatec- } \\
\text { tomy } \\
\text { (all types) }\end{array}$ & $\begin{array}{c}\text { Other } \\
\text { Treatment }\end{array}$ & \\
\hline I and II & $\begin{array}{c}50-69 \\
70 \text { and Over }\end{array}$ & $\begin{array}{l}\frac{2}{58}(3) \\
\frac{9}{63}(13)\end{array}$ & $\begin{array}{l}\frac{2}{13}(15) \\
13 \\
\frac{13}{38}(34)\end{array}$ & $\begin{array}{r}6 \\
22\end{array}$ \\
\hline III & $\begin{array}{c}50-69 \\
70 \text { and Over }\end{array}$ & $\begin{array}{l}\frac{1}{61}(2) \\
10 \\
58\end{array}$ & $\begin{array}{l}\frac{2}{15}(13) \\
\frac{20}{38}(53)\end{array}$ & $\begin{array}{r}4 \\
31\end{array}$ \\
\hline IV and $V$ & $\begin{array}{c}50-69 \\
70 \text { and Over }\end{array}$ & $\begin{array}{l}\frac{4}{53}(8) \\
\frac{8}{55}(15)\end{array}$ & $\begin{array}{c}\frac{0}{8} \\
\frac{15}{36}(42)\end{array}$ & $\begin{array}{r}7 \\
25\end{array}$ \\
\hline Total & & $\frac{34}{348}(10)$ & $\frac{52}{148}(35)$ & 17 \\
\hline
\end{tabular}

The well-known effect of age on prostate mortality is clearly evident as is the higher mortality in cases not treated by prostatectomy - a group largely composed of patients who were unfit for operation.

\section{Hospital Mortality Rates}

86 of the 496 prostate patients died in hospital. These deaths (from all causes) were related to the north-east area population to give hospital mortality rates per 100,000 per annum (Table VI, opposite).

These (hospital deaths per 100,000 population) rates show a social class gradient similar to the allScotland mortality rates in Fig. 1 but are rather higher. This excess is no doubt due to the fact that about $\mathbf{4 0}$ per cent. of the hospital deaths were not attributable to prostate disease but were due primarily to incidental causes, such as heart disease or chronic 
TABLE VI

HOSPITAL DEATHS AMONG PATIENTS ADMITTED WITH PROSTATIC HYPERPLASIA, PER 100,000 POPULATION PER ANNUM, BY AGE AND SOCIAL CLASS

\begin{tabular}{|c|c|c|c|c|}
\hline \multirow{2}{*}{$\begin{array}{l}\text { Social } \\
\text { Class }\end{array}$} & \multicolumn{4}{|c|}{ Age (yrs) } \\
\hline & $60-69$ & $70-79$ & 80 and Over & All Ages \\
\hline $\begin{array}{l}\text { I and II } \\
\text { III } \ldots \\
\text { IV and } v \quad \ldots\end{array}$ & $\begin{array}{l}62 \\
21 \\
40\end{array}$ & $\begin{array}{l}311 \\
160 \\
169\end{array}$ & $\begin{array}{l}811 \\
603 \\
695\end{array}$ & $\begin{array}{l}220 \\
125 \\
147\end{array}$ \\
\hline
\end{tabular}

bronchitis, whereas the Scottish data are based on deaths (in hospital and at home) which were allocated to prostatic hyperplasia. Despite this difference, the relative rise in mortality from age $60-69$ to age 70 and over was very similar in the two sets of rates, but there was a tendency for this increase with age to be rather greater in Social classes III, IV, and V than in Classes I and II. This is to be expected in the light of the earlier data showing the relatively higher admission rates in very old, compared to less old, lower class men.

Cause of death for 66 patients was obtained from the hospital case notes and the death certificates, and for the other twenty from hospital case notes only. The 86 deaths were then divided into two groups. In 48 patients the primary cause of death was attributed to the prostate-usually renal failure or urinary infection, and in the other 38 death was due to some other condition not directly related to the reason for admission-cardiac disease, chronic bronchitis, or bronchopneumonia. The mortality gradients in these two groups are shown in Table VII.

TABLE VII

HOSPITAL DEATHS AMONG PATIENTS ADMITTED WITH PROSTATIC HYPERPLASIA, PER 100,000 POPULATION PER ANNUM, BY SOCIAL CLASS

\begin{tabular}{l|c|c|c}
\hline $\begin{array}{c}\text { Social } \\
\text { Class }\end{array}$ & $\begin{array}{c}\text { Deaths } \\
\text { Related to } \\
\text { Prostate } \\
\text { (per 100,000) }\end{array}$ & $\begin{array}{c}\text { Deaths } \\
\text { Unrelated to } \\
\text { Prostate } \\
\text { (per 100,000) }\end{array}$ & $\begin{array}{c}\text { All Deaths } \\
\text { (per 100,000) }\end{array}$ \\
\hline I and II & 136 & 84 & 220 \\
III IV and V & 68 & 57 & 125 \\
IV all $\quad$. & 76 & 72 & 147 \\
\hline All & 85 & 67 & 152 \\
\hline
\end{tabular}

There is a higher mortality in the upper social classes in both groups, but the excess is much greater where death was attributed to prostate disease; in this group of prostate-related deaths, two-thirds of the patients had undergone surgery and it may therefore be suggested that, although operative mortality was the same in each social class, the higher death rate per 100,000 population simply reflects the fact that relatively more upper class patients come to surgery and as a result relatively more die. That this is not the sole explanation of the observed mortality gradients is shown by the fact that even among patients not subjected to surgery there was a tendency for the death rate to be higher in the upper social class.

These findings raise the possibility that a difference between certification of cause of death at home and in hospital is responsible for the observed mortality gradients by social class. If reason for admission to hospital-in this case, prostate disease-were to influence selection of cause on the death certificate, whereas at home death was more likely to be assigned to some other cause (and in the elderly other chronic disease frequently coexists), then because more upper class men are admitted to hospital with prostate disease it might be that their deaths would be more often attributed to that condition. This is at the moment only a hypothetical explanation and further study of causes of death at home and in hospital is required to elucidate it.

\section{Discussion}

The evidence adduced in this paper does not clearly point to either a biological or sociological explanation of the facts concerning prostate disease and social class. If the association between upper social class and higher mortality from prostatic hyperplasia is real, i.e. if anomalies of death certification are not responsible for the association, then the autopsy data, whilst not conclusive either way, suggest that further study of prostate weight and social class might reveal a higher prevalence of prostatic hypertrophy in Classes I and II. On the other hand the distribution of nocturia (including previous prostatectomy) does not favour the true prevalence hypothesis, though it must be admitted that the accuracy of statements on symptoms is open to question.

What does seem fairly clear is that upper class men are more often admitted to hospital or nursing home with benign prostatic hypertrophy, and that a result of this is their higher mortality per head of population. Possible explanations for this higher admission rate are that professional men are more embarrassed socially by the troublesome symptoms of prostatic obstruction or perhaps they are more aware than lower class men of the cause of these symptoms and what can be done to relieve them. Koos (1960) has quoted some support for these views but further work is necessary to substantiate this sociological hypothesis. A field study, perhaps organized through general practice, could be designed to test both this idea and the possibility that choice of cause of death in prostatic cases differs between home and hospital in the various social classes. 


\section{SUMMARY}

National death rates from hyperplasia of the prostate are higher in the upper social classes. A study of hospital patients in north-east Scotland has shown that men in Social Classes I and II also have a higher admission rate for prostate disease. There was no difference between social classes in type of treatment or case fatality rate, but hospital deaths related to the population at risk gave mortality rates with a social class gradient similar to the national figures.

Variation in death certification, and differences between social classes either in the true prevalence of prostatic hyperplasia or in their reaction to the symptoms of prostatic obstruction, are put forward as explanations of these mortality and morbidity findings. Evidence from an autopsy study tends towards the biological hypothesis but a survey of nocturia in older men did not support this view. The possibilities that choice of cause on death certificates varies with place of death and that professional men are more likelv to seek treatment than men in other social classes also remain open for further research.

I wish to thank Mr W. B. Mawson and Mr M. H. Carson, records officers in Aberdeen Royal Infirmary, for their help with the heavy task of selecting and checking case notes; Dr Alwyn Smith, who provided the special tabulations from the Scottish Hospital In-patient Survey; the Registrar General for Scotland, for the mortality data; Dr Graeme Nicol, of the University Department of Pathology, for his co-operation and interest in the autopsy study; Dr S. J. Kilpatrick, for statistical guidance and calculation; and $\mathrm{Dr} W$. R. S. Doll, Prof. E. M. Backett, and Dr R. D. Weir, for reading the draft and suggesting many improvements.

\section{REFERENCES}

Koos, E. L. (1960). In "Sociological Studies of Health and Sickness", ed. Dorrian Apple, pp. 9-14. McGraw-Hill, New York.

Registrar General (1958). "Occupational Mortality, Decennial Supplement, England and Wales, 1951." Part II, vol. 1. HMSO, London.

Richardson, I. M. (1964). "Age and Need." Livingstone, Edinburgh.

Walker, K. M. (1922). Brit. med. J., 1, 297. 